\title{
Editorial Foreword 76.2 (May 2017)
}

\section{Our Cover}

This month's cover illustration comes from James R. Reichert, the author of an article in this issue. Utagawa Kunisada II provided this polychrome image for the cover of the first volume of Inu no sôshi, the gôkan adaptation of Hakkenden. The bright, almost garish illustration typifies the aesthetics favored by consumers of these cheap, easy-to-read, late-Edo publications and nicely complements the action-packed content of the written narrative.

\section{IN THIS IssuE}

The Journal of Asian Studies has long been an interdisciplinary publication, routinely showcasing work by scholars in many humanities and social science fields. Still, this issue may cover a wider range of disciplines than any to date, thanks to its inclusion of work by people trained in the natural and physical sciences. They are part of the symposium Catastrophic Asia, found at the end of the Research Articles section.

The articles preceding the symposium can be divided neatly into three parts: two essays on politics, each of which deals partly or exclusively with Thailand; two essays on Japanese literature; and two essays on South Asia and issues of colonialism, focusing in one case on Bengal and in the other on Sri Lanka. The issue and the pair of articles on Thailand opens with political scientist Tyrell Haberkorn's "The Anniversary of a Massacre and the Death of a Monarch," an Asia Beyond the Headlines article that offers a detailed look at events staged last fall to commemorate the passage of forty years since the October 6, 1976, killings at Bangkok's Thammasat University. These took place in the constrained setting of post-coup Thailand, but just before the death of the country's long-reigning king put new restrictions on public gatherings. The author pairs a thick description of memorial ceremonies honoring victims of past state violence with official mourning rituals for an elderly monarch who died of natural causes, while also offering some comparative comments that address memory and commemoration debates associated with massacres in other parts of Asia, including the killings in Indonesia in the mid-1960s that were the subject of a recent Asia Beyond the Headlines essay.

Ray Christensen and Joel Sawat Selway's "Pork-Barrel Politics and Electoral Reform: Explaining the Curious Differences in the Experiences of Thailand and Japan" completes the two-part opening section. As its title suggests, it is explicitly and comprehensively comparative in nature. The "puzzle" that the authors grapple with is why Thailand and Japan, though undertaking "similar electoral reforms at about the same time," now find themselves in such different situations, with the former under 
military rule after a coup, while the latter continues to function as a democratically ruled society.

The next pair of articles are James R. ReichenT'S "From Yomihon to Gôkan: Repetition and Difference in Late-Edo Book Culture" and Michiko Suzuki's "Reading and Writing Material: Kôda Aya's Kimono and Its Afterlife," both of which are the works of specialists in Japanese literature. The former is concerned with the "two categories of printed books that dominated the Japanese commercial publishing industry in the midnineteenth century," genres that he translates to mean "reading books" (that were written in a style that "combined elements gleaned from the Japanese and Chinese classics" and created with "high production values") and "assembled volumes" ("cheaply produced publications distinguished by the prominence of their illustrations"), respectively. In exploring the relationship between these types of books, the author draws effectively on work by Roger Chartier - a French historian of the book-to tease out interesting parallels between the early modern European and Japanese cases. Suzuki's article zeroes in on developments of the twentieth century, using Kôda's writing on kimonos to offer a "new view" of the author and one of her novels, while also "engaging with broader questions of material and cultural representation, and the role of objects in the interpretation of literary texts." A contribution to the ongoing "material turn," Suzuki's piece is predicated on the idea that there is great value in cultivating the skill of "listening to the unexpected stories that things tell" in works of fiction.

The final pair of essays that come before Catastrophic Asia and the book reviews that conclude the volume are SATAdru SEn’s “The Conservative Animal: Bhudeb Mukhopadhyay and Colonial Bengal" and Harshana Rambukwella's "Locations of Authenticity: S. W. R. D. Bandaranaike of Sri Lanka and the Search for Indigeneity.” Sen, a New Yorkbased historian, strives to locate the essayist of primary interest to him "within the history of colonial Bengal and a wider world of racial anxieties," while shedding new light on "the foundations of Indian conservatism." Rambukwella, whose main position is in the English Department at the Open University of Sri Lanka, meanwhile, is interested in the "contradictions and ironies" associated with the ideas of a complex man who is "remembered as a heroic anti-colonial figure" and became one of his country's first prime ministers.

The essays and commentaries in our special section on catastrophe in Asia complete the articles section, coming just before the reviews of single books and multi-book essays that close every issue. The section comes with a very fine introduction of its own, written by Тімотну OAKES, which highlights the connections between what the authors in this collection have to say and the discussion in a "JAS at AAS" forum on the Anthropocene that we published in November 2015. Bridget Hanna examines the effects of the Bhopal Gas Disaster, specifically the failings of the long-term epidemiological studies of the disaster's effects, noting that political decisions about who could be described as affected skewed the studies, with catastrophic consequences for both victims and scientific knowledge. Magdalena E. STawkowski shifts our gaze to a Soviet-era nuclear test site in Kazakhstan, where the "legacy of Soviet exploitation, economic growth, and protecting its populations" each come into play, yet risk remains downplayed by citizens and government. Owen B. Toon, Alan Robock, Michael Mills, and Lili Xia are scientists who combined their efforts to warn against the tremendous risks of political conflict in Asia resulting in the use of nuclear weapons. Alāna M. Wilson, Sierra Gladfelter, Mark W. Williams, Sonika Shahi, Prashant Baral, Richard Armstrong, 
and ADina RACOVITEANU are geographers and climate scientists examining the precarity of water resources in the Himalayas. Donna M. Goldstein and Emily T. YeH round out the symposium with perspectives from the fields of geography and anthropology.

\title{
Forthcoming Articles in JAS 76.3 (August 2017)
}

\author{
Research Articles
}

"Is Peking Man Still Our Ancestor?"-Genetics, Anthropology, and Politics of Racial Nationalism in China

Yinghong Cheng

The Munitions Worker as Trickster in Wartime Japan

Benjamin T. UChiYAma

Speaking in Tongues? Daimyo, Zen Monks, and Spoken Chinese in Japan, 1661-1711 Rebekah Clements

Uncanny Hybridity and Nostalgia Politics in The Yellow Sea

Suk Koo Rhee

Spatializing Enlightened Civilization in the Era of Translating Vernacular Modernity: Colonial Vietnamese Intellectuals' Adventure Tales and Travelogues, 1910s-1920s Yufen Chang

From the Commission to the Mission Model: Technology Czars and the Indian Middle Class

ITTY ABRAHAM

Gendered Care Work as "Free Labor" in State Employment: School Social Workers in the Education Welfare (Investment) Priority Project in South Korea JESOOK SONG

Before 1962: The Case for 1950s China-India History Arunabh Ghosh 